\title{
Creating confident scientific writers engaged in productive writing and editing using a portfolio approach (Retraction Notice)
}

Stacia Vargas, Paul Hanstedt

Stacia K. Vargas, Paul Hanstedt, "Creating confident scientific writers engaged in productive writing and editing using a portfolio approach (Retraction Notice)," Proc. SPIE 11143, Fifteenth Conference on Education and Training in Optics and Photonics: ETOP 2019, 111430M (2 July 2019); doi: $10.1117 / 12.2511472$

SPIE Event: Fifteenth Conference on Education and Training in Optics and Photonics: ETOP 2019, 2019, Quebec City, Quebec, Canada 


\section{Creating confident scientific writers engaged in productive writing and editing using a portfolio approach (Retraction Notice)}

Stacia K. Vargas ${ }^{1}$, Paul Hanstedt2

IVirginia Military Institute (United States)

2Roanoke College (United States)

Proceedings Volume 11143, Fifteenth Conference on Education and Training in Optics and Photonics: ETOP 2019; $111430 M$ (2019) https://doi.org/10.1117/12.2511472

Event: Fifteenth Conference on Education and Training in Optics and Photonics: ETOP 2019, 2019, Quebec City, Quebec, Canada

Online Publication Date: 2 July 2019

Withdrawn from Publication: 22 April 2021

Publisher's Note: This paper, originally published on July 2, 2019, was retracted from the SPIE Digital Library on April 22, 2021, due to similarities between specific portions of the text of the paper to the following publication:

S. K. Vargas and P. Hanstedt, "Exploring Alternative in the Teaching of Lab Report Writing: Deepening Student Learning Through a Portfolio Approach," Double Helix Vol. 2 (2014). doi: 10.37514/DBH-J.2014.2.1.07 